Jurnal Ilmu Sosial dan Pendidikan (JISIP)

Vol. 6, No. 1 Januari 2022

e-ISSN : 2656-6753, p-ISSN: 2598-9944

DOI: 10.36312/jisip.v6i1.2745/http://ejournal.mandalanursa.org/index.php/JISIP/index

\title{
Analisis Terhadap Kebijakan Pembinaan Anak Jalanan Di Kota Makassar
}

\author{
${ }^{1}$ Arpin, ${ }^{2}$ Andi Agustang, ${ }^{3}$ Andi Muhammad Idkhan \\ ${ }^{1,2,3}$ Universitas Negeri Makassar
}

\section{Article Info}

Article history:

Received 22 Desember 2021

Publish 04 Januari 2022

\section{Keywords:}

Analisis,

Kebijakan,

Pembinaan Anak Jalanan.

\section{Corresponding Author:}

Arpin

Universitas Negeri Makassar

Email: arpinnono@gmail.com,

\section{PENDAhUluan}

Pasal 34 ayat (1) Undang Undang Dasar Negara Republik Indonesia Tahun 1945 (UUD NRI 1945) mengatur bahwa "Fakir miskin dan anak terlantar dipelihara oleh Negara". Artinya Negara dalam hal ini pemerintah bertanggungjawab terhadap pemeliharaan dan pembinaan fakir miskin dan anak-anak terlantar, termasuk anak Jalanan dan gelandangan. Hak asasi fakir miskin, anak terlantar, anak jalanan dan gelandangan, pada hakekatnya sama dengan hak-hak asasi manusia pada umumnya, sebagaimana tercantum dalam UU No. 39 Tahun 1999 tentang Hak Asasi Manusia, dan Keputusan Presiden RI No. 36 Tahun 1990 tentang Pengesahan Convention on the Right of the Child (Konvensi tentang Hak-hak Anak). Mereka perlu mendapatkan hak-haknya secara normal sebagaimana layaknya anak lainnya, yaitu hak sipil dan kemerdekaan (civil righ and freedoms), lingkungan keluarga dan pilihan pemeliharaan (family envionment and 
alternative care), kesehatan dasar dan kesejahteraan (basic health and welfare), pendidikan, rekreasi dan budaya (education, laisure and culture activites ), dan perlindungan khusus (special protection).

Kepedulian terhadap kesejahteraan anak sebagai bagian peningkatan sumber daya manusia, pemerintah juga telah pernah mengeluarkan Undang-Undang Republik Indonesia No 4 Tahun 1979 Tentang Kesejahteraan Anak dan Undang Undang Republik Indonesia No 23 Tahun 2002 Tentang Perlindungan Anak. Kaitan probelmatika anak dengan negara, tugas utama negara adalah memerdekakan warga dari kemiskinan. Karena itulah, para pendiri negara ini merumuskan aturan dasar bahwa tiap-tiap warga negara berhak atas pekerjaan dan penghidupan yang layak. Konstitusi pun secara tegas memerintahkan agar fakir miskin dan anak-anak telantar dipelihara atau menjadi tanggungjawab negara, sebagaimana telah dikemukakan sebelumnya.

Berdasarkan data hasil Survei Sosial Ekonomi Nasional (SUSENAS) Badan Pusat Statistik Republik Indonesia Tahun 2008, menunjukkan anak jalanan secara nasional berjumlah sekitar 2,8 juta anak. Dua tahun kemudian, tahun 2010 angka tersebut mengalami kenaikan sekitar 5,4\% sehingga jumlahnya menjadi 3,1 juta. Pada tahun yang sama, anak yang tergolong rawan yang menjadi anak jalanan berjumlah 10,3 juta anak atau 17,6\% dari populasi anak di Indonesia, yaitu 58, 7 juta anak (Soewignyo, 2010).

Penanganan anak jalanan di seluruh wilayah Indonesia pada umumnya belum mempunyai model dan pendekatan yang tepat dan efektif. Keberadaan Rumah Singgah misalnya, belum dapat menjadi solusi efektif menyelesaikan permasalahan anak jalanan dan gelandangan di perkotaan. Pemerintah dalam hal ini, Departemen Sosial RI bekerjasama dengan UNDP (United Nation United Programe) dalam proyek Rumah Singgah INS/94/007 pembuatan Rumah Singgah (Departemen Sosial, 1997: 31) model Rumah singgah (Open House For Street Children), secara konseptual menggunakan metode dan teknik yang meliputi Street Based, Centre Based, Community Based, bimbingan sosial dan pemberdayaan (Depsos RI, 1999: 2) model tersebut yang dapat dikatakan Rumah Singgah merupakan salah satu alternatif strategi dalam penanganan anak jalanan yang dimana di dalamnya telah masuk pemberdayaan anak jalanan pada aspek pendidikan, kesehatan, ekonomi, kesenian dan agama. Secara umum tujuan dibentuknya Rumah Singgah adalah membantu anak jalanan dalam mengatasi masalah-masalah dan menemukan alternatif ikatan dengan keluarganya atau sudah tidak mempunyai ikatan dengan keluarganya.

Lebih lanjut dikemukakan bahwa menyangkut masalah kepedulian pemerintah daerah pada masalah anak-anak, saat ini baru ada sekitar 12 provinsi di Indonesia yang memiliki Peraturan Daerah (Perda) soal anak, yang menyoal juga masalah anak jalanan. Dari 12 provinsi tersebut diantaranya Sumatera Utara (Medan), Jawa Barat (Bandung), Jawa Tengah (Semarang) dan Sulawesi Selatan (Makassar). Seringkali Pemerintah menganggap anak jalanan sebagai pengganggu arus lalu lintas, sumber ketidakteraturan kota terutama keamanan pengguna jalan, ketenteraman lingkungan perumahan dan pertokoan. Sementara aktivis LSM yang berfokus pada pemenuhan hak-hak anak, menuding Perda ini sebagai bentuk marginalisasi, anti orang miskin, diskriminatif, tidak berwawasan HAM, tidak peka jender dan tidak ramah anak (child friendly ).

Hal ini terlihat dari kampanye yang dilakukan Dinas Sosial, yang mengancam akan menjatuhkan sanksi berupa denda bagi orang yang memberi uang di jalan. Begitupun, patroli dan pendirian posko lengkap dengan Polisi dan Satpol PP yang kehadirannya sebagai pos jaga dan terkesan upaya untuk "menakut-nakuti”. Belum lagi wacana mempulaukan Anak Jalanan, sebagai upaya memberi efek jera, dinilai sangat tidak manusiawi. Pandangan Pemerintah Kota Makassar ini menjadi ironi lantaran dicantumkan pada bagian "menimbang" dalam Perda tersebut, bahwa mengingat keberadaan anak jalanan cenderung membahayakan dirinya sendiri dan/atau orang lain dan ketentraman di tempat umum serta memungkinkan mereka menjadi sasaran eksploitasi dan tindak kekerasan, sehingga perlu segera dilakukan penanganan secara konfrehensif, terpadu dan berkesinambungan. Kata penanganan lebih bersifat represif. 
Keberadaan Peraturan Daerah Kota Makassar Nomor 2 Tahun 2008 Tentang Pembinaan Anak Jalanan, Gelandangan, Pengemis Dan Pengamen Di Kota Makassar, selanjutnya disingkat Perda Kota Makassar No. 2 Tahun 2008, tetap perlu diapresiasi sebagi sebuah langkah maju untuk mengisi kevakuman hukum menyangkut anak jalanan. Lagi pula, Perda akan memiliki bobot fungsi untuk meminimalisir kesenjangan undang-undang nasional dan menjaga harmonisasi pelaksanaan program-program intervensi secara teknis. Kemudian, tidak bisa dipungkiri ada nilai-nilai budaya tradisional dari tiap daerah yang mempengaruhi cara pandang dan pola asuh orangtua terhadap anak. Dengan Perda berarti semangat nilai-nilai budaya tradisional akan diakomodasi. Dengan begitu, Perda lebih sejalan dengan kondisi daerah setempat. Bila, peraturan hukum cocok dengan situasi dan kearifan budaya lokal maka ia lebih bisa diterima dan dipatuhi. Hanya saja, yang perlu dibereskan pertama-tama adalah soal definisi tentang siapa "anak jalanan" itu. Sebab, ditilik dari namanya, Perda ini membedakan anak jalanan, gelandangan, pengemis dan pengamen. Padahal, Farid dan Adidananta (2002) dalam Agus Arief (2008 : 6-7) mengatakan bahwa berbagai survei, penelitian atau program intervensi anak jalanan sering memasukkan kategori-kategori, seperti kuli pasar, kuli pelabuhan, kernet angkutan kota, pemulung, atau mereka yang dijerumuskan di dunia prostitusi ke dalam kelompok anak jalanan. Memang, ada kemungkinan terdapat kasus-kasus di mana seorang anak dimasukkan sekaligus ke dalam kategori "anak jalanan", "buruh anak" dan "anak yang dilacurkan".

Tidak bisa dipungkiri, bahwa latar belakang mengapa peraturan daerah itu dibuat, diantaranya bahwa fakta dan kenyataannya di balik berlagak pengemis, biasanya ada sindikat yang mengaturnya, yang sengaja menciptakan cacat tubuh dan kepapaan sebagai komoditas yang menyentuh rasa iba. Adalah juga kenyataan, ada anak bayi diculik dan dijadikan pengemis yang selanjutnya dieksploitasi oleh orang yang tidak bertanggungjawab dengan modus menjadi pengemis dijalanan. Namun, penyalahgunaan kemiskinan itu tidak dapat dijadikan alasan untuk membuat peraturan daerah yang menggeneralisasikan pengemis dan aktivitas lainnya sebagai kejahatan. Lalu negara seakan-akan bisa lepas tangan dari tanggung jawab konstitusional untuk menanggung fakir miskin dan anak terlantar.

Pemerintah Daerah Kota Makassar mencoba membuat 'terobosan' kebijakan. Contohnya adalah mengeluarkannya Perda Kota Makassar No. 2 Tahun 2008 Tentang Pembinaan Anak Jalanan, Gelandangan, Pengemis Dan Pengamen. Salah satu 'terobosan' yang diatur dalam Perda ini adalah mengenai larangan dan memuat ancaman hukum kurungan dan sanksi pidana selain hukuman aministrasi kepada masyarakat yang memberikan sejumlah uang atau sedekah kepada anak jalanan, gelandangan, pengemis dan pengamen di tempat umum. Dan pada akhirnya 'terobosan' kebijakan itu mengundang banyak sorotan dan kritik dari berbagai elemen masyarakat dan kalangan akademisi, praktisi hukum serta penggiat Hak Asasi Manusia.

Ketentuan yang memuat larangan yang berisi ancaman hukuman pidana dalam Perda pembinanaan anak jalan, gelandangan, pengemis dan pengamen sudah diberlakukan di beberapa daerah. Contohnya sanksi administrasi dan/atau hukuman kurungan; seperti sanksi pidana berupa kurungan paling lama 3 (tiga) bulan termuat pada Perda Kota Makassar No. 2 Tahun 2008, dan denda menjadi tidak sinkron dengan prinsip hukum pidana sebagai ultimum remedium. Ada beberapa hal dimana penjatuhan sanksi pidana menjadi tidak tepat, apalagi kalau sifatnya pelanggaran terhadap Perda. (baca Pasal 54 ayat (1) dan (2) Perda Kota Makassar No. 2 Tahun 2008).

Kecaman terhadap Perda itu juga datang dari Saldi Isra. Pakar Hukum Tata Negara Universitas Andalas (sekarang Hakim Mahkamah Konstitusi RI) ini malah menilai Perda itu sebagai sebuah upaya mencuci tangan dan 'potong kompas' untuk menyelesaikan masalah gepeng di perkotaan. Padahal dalam konstitusi jelas tugas negaralah yang memelihara kaum miskin dan anak terlantar. Karena pemerintah tidak memelihara dengan baik, maka munculah fenomena gepeng. Ini yang tidak pernah dipikirkan pemerintah untuk mencari solusi pemecahannya. 
(Kompas 12/10/2007) selain itu, Perda yang mengatur tentang gepeng tersebut juga tidak sesuai dengan materi muatan perundang-undangan yaitu materi Perundang-undangan harus mencerminkan asas kemanusiaan. (Pasal 6 ayat (1) huruf b Undang-Undang Republik Indonesia No. 12 Tahun 2011 Tentang Pembentukan Peraturan Perundang Undangan sebagaimana telah diubah dalam Undang Undang Nomor 15 Tahun 2019 Tentang Perubahan Atas Undang-Undang Republik Indonesia No. 12 Tahun 2011 Tentang Pembentukan Peraturan Perundang Undangan).

Penolakan dan kontraversi atas Perda tentang Anak Jalanan, Gepeng, Gelandangan, Pengemis dan Pengamen sering disuarakan oleh berbagai elemen masyarakat, LBH dan bahkan kalangan Akademisi lantang disuarakan. Tercatat Lembaga Bantuan Hukum Makassar, pernah menegaskan kesiapannya mendampingi korban pemberlakuan Perda Anjal. LBH Makassar dalam siaran persnya yang diterima redaksi Fajar, Selasa 1 Juli Tahun 2008, beberapa pekan setelah Perda Kota Makassar No. 2 Tahun 2008 disahkan oleh DPRD Makassar, menurutnya Perda itu masih sangat jauh dari harapan. Alasannya, Perda ini menandakan pemerintah tetap melihat anjal dan seprofesinya sebagai pelaku kriminal yang harus dihukum (Fajar, 02 juli 2008).

Melihat banyaknya permasalahan yang sangat urgen dalam Perda Kota Makassar No. 2 Tahun 2008 Tentang Anak Jalanan, Pengemis dan Pengamen, seperti ketentuan pidananya, baik yang berkaitan karena over kriminalisasi, bertentangan dengan KUHP atau perundang-undangan lain yang lebih tinggi dan ketidak sesuaian dengan Materi Muatan Peraturan Perundangundangan, dan mengingat Perda tersebut juga telah memasuki tahun ke 12 sejak disahkannya, sehingga sudah banyak muatan materi dan isinya tidak lagi sesuai kondisi perkembangan pembangunan Kota Makassar yang sangat pesat, sehingga dengan sendirinya perubahan dan perkembangan sosial, politik, ekonomi, kemasyarakatan dan berbagai peraturan daerah, sehingga perlu dilakukan pengkajian dan revisi kebijakan Kota Makassar terkait Regulasi pembinaan anak jalanan di Kota Makassar.

\section{METODE PENELITIAN}

\section{Tipe Penelitian}

Penelitian dan pengkajian ini termasuk penelitian lanjutan (follow-up study), yaitu menyelidiki perkembangan dari kebijakan pemerintah kota makassar terkait kebijakan pembinaan anak jalanan sebagaimana diatur dalam Peraturan Daerah Kota Makassar No. 2 Tahun 2008 Tentang Pembinaan Anak Jalanan, Gelendangan, Pengemis dan Pengamen. Penelitian ini menggunakan tipe penelitian yang bersifat deskriftif analisis, dengan pendekatan sosilogis - yuridis normatif.

\section{Jenis dan Sumber Data}

Adapun jenis dan sumber data yang digunakan sebagai dasar untuk menunjang hasil penelitian ini adalah data sekunder, yaitu data yang diperoleh dari sumber-sumber tertentu, seperti peraturan daerah, dokumen-dokumen, hasil penelitian, termasuk juga literatur bacaan lainnya yang sangat berkaitan dengan pembahasan penelitian dan pengkajian ini.

\section{Teknik Pengumpulan Data}

a. Wawancara

b. Studi Dokumen

c. Forum Discussion Group (FGD)

\section{Teknik Analisis Data}

Pada tahap selanjutnya, setelah memperoleh data dan mengelola data tersebut, maka dilanjutkan dengan menganalisis data yang diperoleh baik dari bahan hukum primer maupun bahan hukum sekunder dan membahas permasalahannya dengan penganalisaan data primer dan data sekunder secara kualitatif dan kuantitatif dari sudut pandang ilmu hukum. Data primer dan data sekunder yang diperoleh dari penelitian telah disusun dengan teratur dan sistematis, kemudian dianalisa untuk mendapatkan suatu kesimpulan. 


\section{HASIL DAN PEMBAHASAN}

Berdasarkan hasil pengamatan dan pengkajian ketujuh kelompok sasaran PMKS tersebut diatas, ada beberapa permasalahan sosial yang saling berkaitan. Akar permasalahan yang saling berkaitan didominasi masalah kemiskinan. Kemiskinan dapat mendorong seseorang melakukan tindak kriminal seperti mencuri, menjambret dan merampok. Kemiskinan dapat memicu seseorang untuk berkecimpung di dunia gelap (prostitusi), baik ditingkat lokal, nasional maupun internasional. Perdagangan anak (trafficking), penculikan anak, dan ekploitasi anak untuk mencari nafkah dengan mengemis atau meminta-minta, jualan Koran/tissu diperempatan jalan lampu merah ditengah hiruk pikuknya keramaian lalu-lintas membuat miris bagi yang melihatnya. Tiga permasalahan lain yang disebabkan kemiskinan dan menjadi topik khusus dalam kajian ini adalah gelandangan, pengemis (gepeng) dan anak jalanan (anjal) yang memiliki kesamaan karakteristik. Masalah gepeng dan anjal menjadi pusat perhatian para pemerhati kesejahteraan sosial yang berupaya untuk mengatasinya. Kementerian Sosial dengan program rehabilitasi gepeng melalui panti yang tersebar di Indonesia, belum menunjukkan hasil yang signifikan. Hal tersebut disebabkan:

Pertama, tidak seimbangnya jumlah permasalahan dibanding penanganan kasus. Jumlah panti dan rumah singga dengan tenaga yang menangani tidak sebanding dengan banyaknya kasus yang terjadi dan harus ditangani, dan tidak tuntasnya program rehabilitasi dan pembinaan berkelanjutan yang harusnya dijalankan, sehingga masih banyak gepeng yang berkeliaran.

Kedua, makin berkembangnya pola konsumsi masyarakat yang disebabkan perubahan sosial akibat pesatnya kemajuan dan globalisasi. Mudahnya masyarakat mengakses berita, tontonan yang bernuansa iklan mendorong naiknya pola konsumsi masyarakat sehingga makin banyak orang yang merasa penghasilannya tidak mencukupi. Faktor kedua ada kecenderungan bersifat sosial dan budaya, bukan ekonomi semata. Makin terlihat adanya kenaikan selera masyarakat, dengan banyaknya "iming-iming" yang dilihat setiap harinya. Hal tersebut dapat dilihat munculnya indikator kemiskinan bukan karena mereka tidak bisa makan.

Ketiga, terbatasnya lapangan pekerjaan berbanding terbalik dengan cukup tingginya angka usia kerja yang membutuhkan lapangan pekerjaan, sehingga memicu meningkatnya angka pengangguran yang berimbas pada meningkatnya jumlah kemiskinan di berbagai daerah, sehingga memancing sikap Urban dengan harapan keinginan ke kota mencari pekerjaan, meski pada akhirnya banyak yang gagal mendapatkan pekerjaan dan harapan merubah hidupanya, sehingga menjadi gelandangan, pengemis dan anak jalanan di kota, seperti keberadaan gepeng dan anjal di Makassar.

Berdasarkan hasil pengamatan dan wawancara; diperoleh data bahwa para Gepeng dan Anjal di Kota Makassar, selain memang warga masyarakat Kota Makassar, justru terbanyak ratarata merupakan warga urban berasal dari Kabupaten Gowa, Takalar dan Jeneponto. Hal tersebut juga dikemukakan oleh Kepala Dinas Sosial Kota Makassar, saat di itu dijabat oleh Akhmad Namsum, usai memimpin razia Gepeng dan Anjal, bahwa: "Mereka yang terjaring rata-rata berasal dari luar Makassar. Kebanyakan dari mereka berasal dari Gowa, Takalar, dan Jeneponto. "Ini ratarata dari luar. Banyak dari Takalar, Jeneponto, Gowa. Kami akan cari akar-akarnya. Kalau kami lihat ada yang perlu diberdayakan, kita carikan solusinya untuk tidak lagi tergiur jadi gepeng dan anjal lagi," jelas Namsum, Senin 6 Mei 2019. Sumber: https://makassar.terkini.id/akhmad-namsumpimpin-langsung-razia pengemis-kota-makassar/.

Keberadaan gelandangan, pengemis (Gepeng) dan anak jalanan (anjal) tersebut dianggap masih sulit diatasi di Kota Makassar. Komisi D Bidang kesejahteraan masyarakat (Kesra) menganggap bahwa Makassar memerlukan Shelter penampungan agar penanganan dapat berjalan efektif. Anggota Komisi D Irwan Djafar mengatakan bahwa gepeng dan anjal memerlukan penanganan yang intens. Menurutnya "ini susah-susah gampang, ganpangnya itu dijaring semua, tapi susahnya kita mau tempatkan di mana, kan tidak ada Liponsos (Lingkungan Pondok Sosial)," katanya. Sementara untuk mempidanakan mereka justru tidak mungkin, sehingga satu-satunya 
upaya yang paling efektif adalah mempercepat pengadaan shelter penampungan. Senin 6 Mei 2019. Sumber: https://makassar.terkini.id/akhmad-namsum-pimpin-langsung-razia pengemis-kotamakassar/.

Sementara itu Kepala Seksi (Kasi) Anjal dan Gepeng Dinas Sosial Kota Makassar, Kamil mengakui sulitnya penanganan Gepeng dan Anjal lantaran belum adanya penampungan khusus tempat membina mereka secara intens. Pengadaan dianggap sulit lantaran hal ini merupakan wewenang provinsi. "Itu ada Undang undangnya untuk dinas sosial kota/kabupaten khusus di luar panti, sementara untuk di dalam panti itu kewenangan provinsi atau kementerian," katanya. Kamil mengatakan Makassar sebelumnya pernah memiliki penampungan khusus bagi gepeng dan anjal di Salodong, namun kemudian beralih fungsi oleh kementerian menjadi tempat rehabilitasi bagi orang berkebutuhan khusus. "Jadi susah juga, minset mereka susah diubah apalagi tidak ada sanksi bagaimana itu mereka kan tidak melakukan tindakan kriminal," katanya. (Kamis, 24 September 2020. makassar.sindonews.com/).

Menurut Kepala Dinas Sosial Kota Makassar, Mukhtar Tahir bahwa gagasan program Lingkungan Pondok Sosial (Liposos) sebagai salah satu solusi permasalahan anak jalanan, pengemis dan gelandangan yang menjamur. Program tersebut sudah diusulkan ke Badan Perencanaan Pembangunan Daerah Kota Makassar, sisa menunggu hasil kajian dari Bappeda dan mudah-mudahan ditanggapi dan segera dianggarkan pembangunannya. Menurutnya, "lokasi banyak tempat kecamatan yang kosong, sebelumnya ada di Untia, mudah-mudahan bisa dipakai empat sampai lima hektare di sana". Liponsos sendiri menurut Mukhtar Tahir juga diharapkan bisa menyelesaikan masalah Anjal dan Gepeng di Makassar. Saya lihat di Jogja dan Bandung itu luar biasa, mulai anak terlantar sampai lansia terlantar sudah ada tempat penampungannya. Selain itu, Liponsos nantinya bisa menjadi rumah pelatihan bagi anjal dan gepeng yang terjaring. Dimana nantinya mereka akan dibelaki dengan ilmu-ilmu yang bisa dimanfaatkan di tengah masyarakat. makassartoday.com, Kamis 13 Agustus 2020.

Pemerintah Daerah Kota Makassar bergerak melalui Perda No 2 tahun 2008 tentang Pembinaan Anak jalanan, Gelandangan, Pengemis dan Pengamen di Kota Makassar, Perda No. 3 Tahun 2009 Tentang Pembentukan dan Susunan Organisasi Perangkat Daerah Kota Makassar dan Perwali No. 87 Tahun 2016 tentang Kedudukan, Susunan Organisasi, Tugas Dan Fungsi Serta Tata Kerja Satuan Polisi Pamong Praja. Dalam rangka melaksanakan ketertiban umum, maka perangkat daerah dan dinas terkait melakukan tindakan yang bersifat prevemtif dan represif dengan menurunkan Satpol di areal operasi untuk melakukan pembinaan dan razia pada Gelandangan, Pengemis dan Anak Jalanan dengan menurunkan sejumlah Satuan Pamong Praja. Akan tetapi upaya penertiban gepeng dan anjal memalui razia tentu memang akan dirasakan dampaknya, tapi sifatnya hanya sementara, jika tidak dibarengi dengan upaya pemeliharaan dan pembinaan berkelanjutan, tidak disiapkan liponsos (lingkungan pondok sosial) dan rumah singgah atau shelter sebagai tempat penampungan untuk pemeliharaan, pembinaan dan rehabilitasi pasca razia gepeng dan anjal.

Selanjutnya pihak Pemerintah Daerah berkoordinasi dengan Dinas Sosial untuk melakukan pembinaan tidak lanjut dengan tujuan akhir membuat mereka tidak kembali ke jalan-jalan, dengan harapan dapat melaksanakan fungsi sosialnya. Usaha tersebut dapat mengatasi permasalahan gepeng dan anjal, namun hanya bersifat sementara. Gepeng dan anjal kembali bergerak menyebar di berbagai tempat yang dianggap strategis seperti diperempatan jalan protokol dan lampu merah, rumah makan, restoran, rumah ibadah dan daerah sekitar perparkiran. Hal tersebut dimungkinkan kurangnya pendampingan ketika mereka ditampung setelah dirazia. Penanganan masalah gepeng dan anjal harus dilaksanakan secara terpadu dengan pihak swasta dan melibatkan masyarakat. Sebenarnya beberapa lembaga swadaya masyarakat telah memberikan pendampingan melalui wadah 'rumah singgah', akan tetapi upaya tersebut juga belum dapat menunjukkan hasil yang memuaskan, namun paling tidak sudah ada penanganan meskipun tidak dapat menyelesaikan 
permasalahan secara tuntas. Penampungan hasil razia gepeng dan anjal memerlukan penanganan yang kompleks. Pertama masalah tempat penampungan, pemerintah kota perlu menyiapkan lokasi untuk penampungan baik berupa panti asuhan, rumah singga, tempat rehabilitasi, pembinaan dan pelatihan. Kedua, ketersediaan logistik yang biayanya tentu tidak sedikit, dan Ketiga, perlu tenaga terampil dan khusus yang mendampingi mereka selama di penampungan dan tempat rehabilitasi, Keempat, diperlukannya bentuk program, modal dan kegiatan untuk mengalihkan agar mereka tidak kembali dijalanan. Cara menangani gepeng dan anjal tersebut memerlukan anggaran yang besar. Melihat masih seringnya gepeng dan anjal berkeliaran di jalan mengindikasikan belum ditemukannya cara ataupun solusi yang tepat untuk menangani permasalahan gelandangan dan anak jalanan.

Permasalahan Gelandangan Pengemis dan Anak Jalanan menurut para ahli sosial, penyebab adanya gelandangan dan pengemis serta anak jalanan disebabkan krisis ekonomi yang berkepanjangan, kurangnya lapangan pekerjaan yang menyebabkan meningkatnya angka pengangguran dan minimnya keterampilan kerja serta tidak memiliki modal usaha yang cukup untuk membuka usaha dan pekerjaan. Namun secara detail dapat dijelaskan bahwa keberadaan gepeng dan anjal disebabkan terjadinya kemiskinan lokal secara kultural maupun struktural. Bentuk atau jenis kemiskinan yang berbeda memerlukan penanganan yang berbeda pula. Penanganan kemiskian struktural akan berbeda dengan penanganan kemiskinan kultural.

Beberapa faktor penyebab menjadi gelandangan dan pengemis menurut hasil penelitian Tateki dkk (2009) antara lain 1) Tidak mampu bekerja, 2) Tidak punya modal usaha, 3) Tidak punya keterampilan kerja, 4) Tidak punya pilihan lain, dan 5) lebih suka menjadi gepeng. Dari hasil penelitian tersebut alasan tidak punya pilihan lain paling dominan yaitu 36,67 persen responden memilih jawaban tersebut. Pesebaran jawaban arahnya merata, artinya 5 alasan menjadi gepeng sesuai dan menjawab faktor penyebab mereka menjadi gepeng. Dari kelima faktor penyebab tesebut point yang kelima inilah yang masih perlu dikupas mengapa mereka lebih senang menjadi gepeng.

Menurut Suparlan (1984) faktor-faktor yang mendorong orang-orang berurbanisasi dan menjadi gepeng antara lain; 1) Lajunya pertumbuhan penduduk di perdesaan, 2) Kondisi daerah perdesaan, 3) kondisi lapangan kerja, 4) warisan hidup menggelandang, 5) Faktor alam atau musibah/ bencana. Kelima faktor yang dikemukakan Parsudi Suparlan tersebut masih relevan dengan kondisi saat ini. Laju pertumbuhan penduduk berimplikasi pada meningkatnya angka ketergantungan, yaitu besarnya usia produktif tidak diimbangi banyaknya lapangan pekerjaan, sehingga terjadi peningkatan jumlah pengangguran. Kondisi daerah perdesaan yang kurang produktif, misalnya makin sempitnya lahan pertanian, kondisi tanah tandus menjadi salah satu faktor pendorong penduduk perdesaan melakukan urbanisasi ke kota. Keterbatasan lapangan kerja formal dan informal juga menjadi salah satu pendorong munculnya gepeng dan anjal. Faktor bencana alam yang terjadi tidak terduga juga menjadi penyebab munculnya masalah sosial gepeng dan anjal.

Kondisi disharmoni yang dirasakan sebagian anggota kelompok tersebut mendorong mereka untuk pergi meninggalkan kelompoknya dan bermigrasi menuju perkotaan yang tidak ada kelompok yang mengikat. Kehadiran mereka dengan harapan mengadu nasib yang lebih baik dari kehidupan desa yang sudah dirasakan tidak menjanjikan untuk memperbaiki kehidupan ekonominya. Gepeng datang dengan berkelompok maupun perorangan. Kondisi kota tidak seperti yang dibayangkan, Media Informasi Penelitian Kesejahteraan Sosial, Vol. 39, No. 1, Maret 2015, 79-89 84 seperti mudah mencari uang, mudah mendapat pekerjaan. Ada sebagian yang dengan cerdas mencari jenis usaha seadanya seperti menjadi kuli bangunan, maupun menemukan pekerjaan buruh yang dapat menghasilkan uang meskipun sedikit. Namun banyak juga yang dalam waktu lama belum dapat menemukan pekerjaan, pada akhirnya memilih untuk hidup dengan meminta minta (mengemis) dan tidak memiliki tempat tinggal (tuna wisma/ gelandangan ). 
Kehadiran mereka mulai terancam dengan adanya Peraturan Daerah (Perda) Kota Makassar No. 2 Tahun 2008 tentang Pembinaan Anak Jalan, Gelandangan, Pengemis dan Pengamen di Kota Makassar, diantaranya mengenai ketertiban umum yang isinya melarang setiap orang untuk memberikan uang kepada pengemis, pengamen, pedagang asongan, serta pembersih mobil dijalanan dan tempat tertentu. Perda tersebut pada awalnya diberlakukan di DKI Jakarta dan pada tahun 2012 sudah diberlakukan di Kota Yogyakarta. Meskipun Perda sudah diberlakukan, namun pelaksanaannya belum terlihat kompak. Sebagai contoh memberi uang receh pada peminta minta dan pengamen jalanan masih sering dilakukan oleh sebagian orang. Mereka masih memberi dengan alasan belas kasihan, ada pula karena takut mobilnya dirusak, meskipun bagi yang melanggar terkena sanksi /denda tidak dihiraukan. Perda yang sudah diberlakukan di Kota Makassar pada tahun 2008 tersebut menuai pro dan kontra. Jika dilihat dari isi Undang-Undang Dasar 1945 Pasal 34 yang berbunyi "Fakir miskin dan anak- anak terlantar dipelihara oleh Negara", maka Perda dapat bertentangan dengan Undang-Undang Dasar 1945. Gelandangan pengemis dan anak jalanan dapat dikategorikan orang-orang miskin, yang seharusnya dipelihara, dibantu, difasilitasi oleh negara untuk mendapatkan hidup yang layak.

Dalam kajian mengenai penanganan gelandangan pengamis dan anak jalanan tentu akan lebih dapat mendekati sasaran apabila kita kaji latar belakang sosial budaya mereka untuk memperoleh model yang lebih kaya dengan pemaknaan, dan dapat diperoleh hasil yang memuaskan. Paling tidak, pihak pengampu kepentingan (pemerintah) tidak mendeskreditkan komunitas gepeng dan anjal, akan tetapi mengakui keberadaannya sebagai bagian dari struktur masyarakat budaya di mana mereka berada. Pekerjaan pemegang kekuasaan adalah membuat komunitas gepeng dan anjal tersebut tidak menjadi kelompok pemicu disharmoni tata kehidupan "kota". Niels Mulder (1985) dalam pendekatan dan analisisnya mengatakan bahwa analisis kultural dilakukan dengan menggali strukturstruktur konsepsi dan mengidentifikasi gagasan sebagai teori kebudayaan. Dengan analisis kultural dimaksudkan untuk memberikan makna dibalik suatu tindakan, dibalik persepsi, klasifikasi dan penafsiran yang sebenarnya. Teori Mulder tersebut dapat dianalogikan untuk memahami struktur budaya masyarakat yang melatarbelakangi gepeng dan anak jalanan dalam menjalani kehidupan barunya. Penelitian mengenai strategi kelangsungan hidup gelandangan-pengemis di Kota Pekalongan oleh Maghfur (2010) menunjukkan bahwa secara kultur gepeng diakui eksistensinya. Gepeng memiliki hari istimewa yaitu Kamis. Pada hari istimewa tersebut gepeng mendapatkan prevellage (keistimewaan), yaitu segala aksi dan perilaku "memintaminta" mendapat permakluman masyarakat. Bagi masyarakat sendiri, mereka merasa harus membagikan rizqinya pada gepeng ketika mendapatkan "gaji mingguan" (pacoan). Dalam konteks tersebut menunjukkan pengakuan masyarakat tentang keberadaan gepeng. Tidak berbeda jauh dari Pekalongan, di Yogyakarta, ketika datang "Grebeg Besar" Keraton Yogyakarta, di alun-alun banyak pengemis (peminta-minta) yang bertebaran memanfaatkan situasi. Pengemis tahu pada saat "grebeg-an" banyak orang berdatangan ingin "ngalap berkah" (mencari berkah/ kemudahan). Selain itu pada hari Jumat di sekitar Masjid Besar (Kauman), para pengemis berbondong bondong mendatangi masjid Kauman untuk mendapatkan sedekah (shodakoh) dari orang-orang yang berada di masjid maupun lingkungan sekitarnya. Pada situasi tersebut, orang beranggapan dengan memberi sedekah pada orang yang meminta-minta menjadi jalan mendapatkan kemudahan untuk mendapatkan "berkah" dan dapat terkabul apa yang diinginkan misalnya rizqi lancar, panen atau dagang lancar serta sebagai penerapan ibadah (agama Islam) untuk saling bebagi rizki pada Gelandangan Pengemis dan Anak Jalanan dari Perspektif Sosial Budaya. Kondisi tersebut dimanfaatkan orang-orang yang sebenarnya masih mampu memenuhi kebutuhan dasarnya pergi ke tempat "grebeg-an" dan hari Jumat mendatangi masjid Kauman menjadi peminta-minta berharap belas kasih dari orang lain.

Selain itu, perlu rehabilitasi dan reintegrasi sosial. Aspek ini menjadi penting karena sebagai anak-anak yang membutuhkan perlindungan khusus (children in need of special 
protection), anak jalanan dan gelandangan mengalami berbagai situasi yang mengakibatkan kondisi fisik, psikis dan moralnya terganggu. Kedua, aspek pelayanan dan rujukan. Perlu diatur tentang bagaimana membuka akses yang seluas-luasnya terhadap anak-anak jalanan untuk memenuhi kebutuhan dasar mereka, seperti akta kelahiran, layanan kesehatan, pendidikan, jaminan sosial dan program lingkungan pondok sosial. Untuk itu, harus dibuat Pedoman Standar Pelayanan Minimal (PSPM) yang menjamin kesejahteraan anak-anak jalanan, anak terlantar dan gelandangan. Penyediaan taman bermain, juga termasuk dalam aspek ini. Ketiga, aspek peningkatan kapasitas dan pemberdayaan ekonomi keluarga. Aspek ini harus memperhatikan secara cermat latar belakang aktivitas ekonomi, minat dan potensi anak serta captive market dari program -program vocational training dan pemagangan yang dilakukan. Keempat, aspek penegakan hukum. Aspek ini perlu memperhatikan penjatuhan sanksi yang dilakukan. Sanksi tegas harus dilakukan terhadap pelaku eksploitasi dan perdagangan anak. Bila orangtua sendiri pelakunya, perlu dipikirkan untuk mencabut hak kuasa asuhnya. Tentu pemerintah harus punya model program pengasuhan maupun pengangkatan anak. Pendekatan pada semua aspek, harus memperhatikan kebutuhan-kebutuhan spesifik dari perempuan dan mendengar pendapat anak-anak jalanan itu.

Agar permasalahan tidak semakin kompleks maka perlu penangan melalui pendekatan sosial dan budaya, antara lain:

Pertama, mereka dikembalikan dengan tatanan sosial dan budaya yang normatif. Salah satu cara yang dapat dilakukan diantaranya menanamkan sikap mental yang baik agar mereka menjadi pribadi yang kuat dan menjauhi tindakan yang tidak terpuji. Selain upaya penanganan mental spiritual, perlu diberikan semacam pelatihan atau kursus agar mereka berdaya, dan mampu mendapat penghasilan secara mandiri dengan bekerja sesuai kemampuannya.

Kedua, perlu dukungan secara kultural dari masyarakat untuk tidak memberikan "sedekah"/belas kasihan pada komunitas gepeng dan anjal di jalanan sehingga mereka tidak lagi menjalankan aksinya dan mengundang mereka kembali kejalan yang dapat mengganggu ketertiban umum dan pengguna dijalan, serta dapat membahayakan keselamatan dirinya.

Ketiga, perlu ada lingkungan Pondokan Sosial (Liposos) dan Rumah Singga atau Shelter bagi gepeng dan anjal pasca razia, dan harus ada pembinaan berkelanjutan, pendampingan dan pembimbingan serta pelatihan keterampilan kerja dan permodalan untuk membuka usaha dan pekerjaan sebagai bentuk kewajiban pemerintah dalam pemeliharaan terhadap fakir miskin dan anak terlantar.

Keempat, dengan menempatkan komunitas gepeng dan anjal menjadi bagian dari keramahan kota maka identitas yang negatif dapat bergeser menjadi sebuah peran positif dalam tatanan kehidupan kota melalui berbagai program pemeliharaan dan pembinaan berkelanjutan bagi gepeng dan anjal melalui pemanfaatan program Lingkungan Pondok Sosial (Liposos).

Selain itu, upaya dan kebijakan pada akhir yang dapat ditempuh oleh pemerintah kota yaitu mengembalikan mereka ke daerah asalnya, melalui koordinasi dan kerjasama antar daerah dan menyiapkan daerah asal untuk mampu memberikan jawaban ketidakberdayaan dalam pemerataan pembangunan, usaha pembukaan lapangan kerja di daerah dan peningkatan kesejahteraan masyarakatnya. Pembukaan lapangan kerja di daerah perdesaan yang tergolong minus (sumber alam tidak mendukung), usaha pelatihan dan peningkatan keterampilan kerja dan berusaha merupakan salah satu solusi yang mungkin dapat mengurangi arus urbanisasi ke kota.

Permasalahan gelandangan, pengemis (Gepeng) dan anak jalanan (Anjal) memerlukan penanganan secara komprehensif dan berkelanjutan dengan tidak melihat sebagai sumber permasalahan hukum dan kriminal semata, tetapi melihat dari perspektif sosial dan budaya. Tindakan persuasif dengan razia yang dilakukan sekarang ini bukan merupakan satu-satunya solusi yang tepat, meski dapat mengatasi gepeng dan anjal berkeliaran di jalan, tapi sifatnya hanya sementara. Perlu dilakukan pendekatan kultur atau budaya gepeng dan anjal. Mereka memiliki 
daerah asal dengan tatanan dan nilai kehidupan. Perlu dikaji alasan mereka meninggalkan daerah asal menuju kota tujuan. Ditempat tujuan mereka membentuk suatu komunitas dengan kebiasaan yang dapat berbeda ketika di daerah asal. Meskipun berbeda, mereka masih memiliki dan memahami tatanan dan nilai-nilai budaya di daerah asalnya. Oleh karena itu perlu bagi pihak yang menangani permasalahan gepeng dan anjal memahami nilai-nilai budaya daerah asal, dengan tujuan dapat menemukan cara yang tepat mengatasi masalah. Imbauan masyarakat untuk menahan belas kasihan (yang merupakan salah satu sikap/budaya) diharapkan dapat mengurangi jumlah gepeng dan anjal secara bertahap. Mengembalikan mereka ke daerah asal dengan mengikuti kehidupan normal dan terbangunnya mental mau bekerja keras menggapai kehidupan yang layak, dan dapat memerankan fungsi sosialnya dengan baik, merupakan langkah yang tepat. Perlunya pengampu kepentingan seperti pemerintah daerah, Kementerian Sosial melalui Dinas Sosial bekerjasama secara terpadu menangani permasalahan berbasiskan kesejahteraan sosial. Perlakuan manusiawi dan mengembalikan harkat martabatnya sebagai bagian dari anggota masyarakat yang berbudaya merupakan pekerjaan yang harus disikapi dengan bijak dan terencana.

\section{KESIMPULAN}

\subsection{Kesimpulan}

Kebijakan pembinaan anak jalanan sebagaimaan diatur dalam Peraturan Daerah Kota Makassar No. 2 Tahun 2008 Tentang Pembinaan Anak Jalanan, Gelandangan, Pengemis dan Pengamen Di Kota Makassar, terdapat muatan materi yang bertentangan dengan amanat konstitusi dan UU penanganan fakir miskin, UU perlindungan anak, Peraturan Hak Asasi Anak, dan UU kesejahteraan sosial memberikan tanggungjawab kepada negara dalam hal ini, pemerintah terhadap pemeliharaan dan pembinaan terhadap fakir miskin dan anak-anak terlantar, termasuk anak Jalanan dan gelandangan. Hak-hak asasi fakir miskin, anak terlantar, anak jalanan dan gelandangan, pada hakikatnya sama dengan hak-hak asasi manusia pada umumnya, Mereka perlu mendapatkan hak-haknya secara normal sebagaimana layaknya anak, yaitu hak sipil dan kemerdekaan (civil righ and freedoms), lingkungan keluarga dan pilihan pemeliharaan (family envionment and alternative care), kesehatan dasar dan kesejahteraan (basic health and welfare), pendidikan, rekreasi dan budaya (education, laisure and culture activites), dan perlindungan khusus (special protection).

\section{SARAN}

Berdasarkan Hasil analisis dan pengkajian yang dilakukan maka:

a. Perlu dilakukan perubahan terhadap Pasal-Pasal Kontraversi pada Peraturan Daerah Kota Makassar Nomor 2 Tahun 2008 Tentang Pembinaan Anak Jalanan, Gelandangan, Pengemis, dan Pengamen Di Kota Makassar. Selanjutnya perlu Perwali sebagai petunjuk pelaksanaan teknis dan acuan pelaksaaan Perda tersebut.

b. Peraturan Daerah Kota Makassar Nomor 2 Tahun 2008 perlu perubahan dan penyesuaian peraturan perundang-undangan yang tinggi dan peraturan perundang-undangan yang baru.

c. Perlu perbaikan dan pemenuhan hak-hak fakir miskin dan anak terlantar sesuai amanat konstitusi dan Peraturan Perundang-undangan.

d. Perlu segera dan sangat mendesak pengadaan Liposos (Lingkungan Pondok Sosial), rumah singga dan tempat penampungan gelendangan, pengemis dan anak jalan atau Shelter untuk penampungan Gepeng dan Anjal.

\section{DAFTAR PUSTAKA}

Agus Arief. 2008. Tinjauan Hukum Kebijakan Pidana dalam Perda Kota Makassar 2008 Tentang Pembinaan Anak Jalanan, Gelandangan, Pengemis. Pascasarjana UNHAS.

Amal, Bakhul Khair. 2003. Pemberdayaan Anak Jalanan Melalui Rumah Singgah: Studi Kebijakan Penanganan Anak Jalanan di Indonesia. Depok: Universitas Indonesia. 
Armai Arief. 2002. Rumah Singgah Sebagai Tempat Alternatif Pemberdayaan Anak Jalanan. Dalam Jurnal Fajar. Jakarta: LPM UIN

Badan Pusat Statistik Republik Indonesia Tahun 2008. Hasil Survei Sosial Ekonomi Nasional (SUSENAS) Badan Pusat Statistik Republik Indonesia Tahun 2008. Jakarta

Departemen Sosial RI. 1992. Diunduh http://sumber-ilmu-islam.blogspot.com/2014, tanggal 4 Maret 2015.

Departmen Sosial RI. 1999. Pedoman Penyelenggaraan Pembinaan Anak Jalanan melalui Rumah Singgah. Jakarta.

Direktorat Jenderal Peraturan Perundang-Undangan Kementrian Hukum dan HAM RI. 2011. Panduan Praktis Memahami Perancangan Peraturan Daerah Edisi Kelima. Jakarta.

Edyanto, and Karsiman. 2018. "Leadership Bupati Dalam Pembangunan Di Kabupaten Tambrauw (Studi Kepemimpinan Bupati Tambrauw)." Sosio e-kons 10(2): 143.

Elly Kumari Tj. P. 2008. Gelandangan dan Pengemis Mengais Keadilan. Yogyakarta : Citra Media. Maghfur Ahmad. 2010. "Strategi Kelangsungan Hidup Gelandangan-Pengemis (Gepeng)". Diunduh http://e-journal.stainpekalongan.ac.id/index.php/penelitian.

Marif. 2019. Bahan Bimbingan Teknis (BIMTEK) Pembentukan Peraturan Daerah bagi Anggota DPRD Kabupaten/Kota. Makassar

Muladi. 1995. Kapita Selekta Hukum Pidana. Badan Penerbit Universitas Diponegoro. Semarang Mulder, Niels. 1985. Pribadi dan Masyarakat di Jawa. Jakarta: Sinar Harapan.

Prayudi Atmosudirjo. 1981. Hukum Administrasi Negara. Ghalia Indonesia. Jakarta.

Suparlan, Parsudi (ed). 1993. Orang Gelandangan di Jakarta: Politik Pada Golongan Termiskin, Kemiskinan di Perkotaan. Jakarta: Yayasan Obor Indonesia.

Tateki Yoga Tursilarini, Warto \& Andayani Listyawati. 2009. Kajian Model Penanganan Gelandangan dan Penanganan Gelandangan dan pengemis. Yoygyakarta: Citra Media.

Twikro, Y. Argo.1999. Pemulung Jalanan Yogyakarta. Konstruksi Marginalitas dan Perjuangan Hidup dalam Bayang-Bayang Budaya Dominan. Yogyakarta: Media Pressindo.

\section{Undang-Undang}

Peraturan Daerah Kota Makassar Nomor 2 Tahun 2008 Tentang Pembinaan Anak Jalanan, Gelandangan, Pengemis Dan Pengamen Di Kota Makassar.

Peraturan Pemerintah Pengganti Undang-Undang Nomor 1 Tahun 2016 Tentang Perubahan Kedua Atas Undang-Undang Nomor 23 Tahun 2002 Tentang Perlindungan Anak.

Undang-Undang Nomor 17 Tahun 2016 Tentang Penetapan Peraturan Pemerintah Pengganti Undang-Undang Nomor 1 Tahun 2016 Tentang Perubahan Kedua Atas Undang-Undang Nomor 23 Tahun 2002 Tentang Perlindungan Anak Menjadi Undang-Undang.

Undang-Undang Republik Indonesia Nomor 11 tahun 2009 Tentang Kesejahteraan Sosial.

Undang-Undang Republik Indonesia Nomor 12 tahun 2011 Tentang Pembentukan Peraturan Perundang-Undangan

Undang-Undang Republik Indonesia Nomor 13 tahun 2011 Tentang Penanganan Fakir Miskin.

Undang-Undang Republik Indonesia Nomor 15 tahun 2019 Tentang Perubahan Atas UndangUndang Republik Indonesia Nomor 12 tahun 2011 Tentang Pembentukan Peraturan Perundang-Undangan.

Undang-Undang Republik Indonesia Nomor 35 Tahun 2014 Tentang Perubahan Atas UndangUndang Nomor 23 Tahun 2002 Tentang Perlindungan Anak. 